\title{
Macroalgal fouling on the intertidal mole crab Emerita analoga facilitates bird predation
}

\author{
Fernando J. Hidalgo • Fausto N. Firstater • \\ Betina J. Lomovasky • Percy Gallegos • \\ Patricia Gamero • Oscar O. Iribarne
}

Received: 22 May 2009/Revised: 18 January 2010/Accepted: 23 February 2010/Published online: 12 March 2010

(C) Springer-Verlag and AWI 2010

\begin{abstract}
In this work, we studied the effects of predation by birds on the intertidal mole crab Emerita analoga fouled by macroalgae in a sandy beach of central Peru $\left(11^{\circ} \mathrm{S}\right)$. The epibiosis affected mostly the larger animals, especially adult females. Epibiosis prevalence for the entire intertidal population was relatively low (1-2\%), however, within the size range affected by epibiosis in the intertidal zone (18-23 $\mathrm{mm}$ in carapace length), $20-38 \%$ of the animals were fouled. Focal observations of birds showed that fouled animals are preferred over those non-fouled of the same size class and hence the same sex, being consumed at a higher rate than their proportion in the intertidal (Chesson's alpha index of prey selection $>0.96$ ), and estimations of mortality rates indicated that more than $35 \%$ of the intertidal fouled animals are removed everyday by birds. The effect of epibiosis may be mainly attributed to a higher burrowing time or an increased visual attractive effect of the algae, which make fouled animals more conspicuous to predatory birds, or because of fouling enhances profitability of the animals.
\end{abstract}

Communicated by H.-D. Franke.

F. J. Hidalgo $(\bowtie) \cdot$ F. N. Firstater · B. J. Lomovasky ·

O. O. Iribarne

Laboratorio de Ecología, Departamento de Biología,

FCEyN, Universidad Nacional de Mar del Plata,

CC 573 Correo Central, B7600WAG, Mar del Plata, Argentina

e-mail: fhidalgo@mdp.edu.ar

B. J. Lomovasky · O. O. Iribarne

Consejo Nacional de Investigaciones Científicas y Técnicas

(CONICET), Buenos Aires, Argentina

P. Gallegos · P. Gamero

Facultad de Ciencias Biológicas (grupo DePSEA),

Universidad Nacional Mayor de San Marcos,

Apartado 1898, Lima 100, Peru
The results show that epibiosis has negative effects on E. analoga through increasing predation by birds, which in turn restricts the distribution and abundance of fouled E. analoga in the intertidal zone.

Keywords Emerita analoga - Epibiosis · Indirect interactions · Peru · Predation · Sandy beach

\section{Introduction}

Indirect interactions may be an important cause of variation in populations and communities (e.g., Menge 1995). Indirect interactions occur via two basic ways (Wootton 1993): (1) due to linked direct interactions between species pairs (i.e., interaction chain) and (2) when a third species change how a pair of other species interact (i.e., interaction modification). By modifying the body surface properties of an organisms through tactile, visual, or chemical cues, epibionts can attract or repel predators, modulating in this way consumer-prey interactions (e.g., Wahl and Hay 1995; Wahl et al. 1997; Laudien and Wahl 2004).

Many hypotheses concerning sandy beach communities have developed over the past two decades, putting sandy beach studies into an increasing theoretical framework (e.g., Defeo and McLachlan 2005). Main generalizations concern the increase in species richness and abundance from reflective to dissipative beaches (e.g., McLachlan and Dorvlo 2005) and the increasing importance of biological factors (e.g., competition) in controlling community structure and population dynamics in dissipative beaches (e.g., Defeo et al. 1997, Dugan et al. 2004), whereas at reflective beaches, populations are physically controlled (Defeo et al. 1997, Defeo and McLachlan 2005). Despite these advances, the importance of other forces such as 
predation, parasitism, or epibiosis is still poorly studied (Defeo and McLachlan 2005; but see Takahashi et al. 1999, Manning and Lindquist 2003).

In protected to moderately exposed sandy beaches within and outside the Ancón Bay (central Peru: $11^{\circ} 46^{\prime} \mathrm{S}$, $77^{\circ} 11^{\prime} \mathrm{W}$ ), an epibiontic association between green macroalgae (Enteromorpha spp.) and the mole crab Emerita analoga (Crustacea, Anomura, Hippidae; Fig. 1) was recently described (Firstater et al. 2009). Emerita analoga is a widespread and abundant decapod inhabiting sandy beaches of the temperate west coast of America (Efford 1969; Contreras et al. 1999; Lépez et al. 2001) and is a characteristic species of the swash zone (Contreras et al. 1999), frequently dominating in abundance and biomass the intertidal macrofauna of sandy beaches (e.g., Dugan et al. 2000). Given its abundance, E. analoga often plays an important role in the secondary production of sandy beaches (e.g., Alvitres et al. 1998), being consumed by several predatory birds that use the intertidal zone for feeding (e.g., Blokpoel et al. 1992; Hubbard and Dugan 2003). The association between green macroalgae and $E$. analoga has a seasonal pattern, being fouled animals present only during summer and absent during winter, possibly because macroalgae growth is enhanced in warmer water conditions (Firstater et al. 2009). Furthermore, the association was found in one of the most productive marine systems (Tarazona et al. 2003), and it is likely that nutrients play an important role on its development (Valiela et al. 1997; Firstater et al. 2009). Epibionts attach to the anterior part of the carapace and first appendages, forming a dense, flossshape mat, usually one to twofolds the surface of the animal (Firstater et al. 2009; Fig. 1a). Epibiosis affects mainly the larger individuals of the population, with neutral effects on demographic and life history parameters of E. analoga, but with a positive effect on their body condition (Firstater et al. 2009). Fouled animals have longer burrowing times than those non-fouled, and when animals are buried into the sediment, the mat of attached macroalgae remains always above the sediment surface (Firstater et al. 2009; Fig. 1b). The negative effect on burrowing ability is attributed only to the epibiosis, since burrowing time is reversible when macroalgae is experimentally removed (Firstater et al. 2009). The reduced burrowing ability of fouled E. analoga, and the potential visual attractive effect of the macroalgae, suggests that the epibiosis might increase the predation risk by birds and hence its mortality rate.

In this work, we evaluate the importance of predation by birds on intertidal $E$. analoga fouled by macroalgae in a sandy beach close to the Ancón Bay. In particular, we (1) investigated the epibiosis prevalence by macroalgae on the intertidal population of E. analoga, (2) calculated and compared predation rates by birds on fouled and
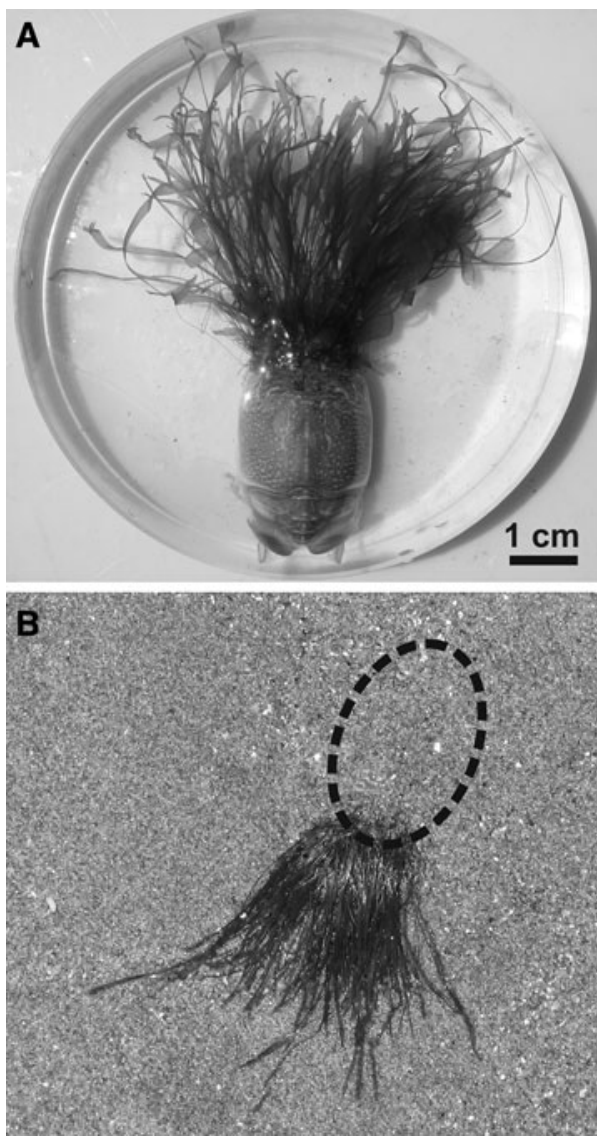

Fig. 1 a Green macroalgae epibiont attached to the anterior part of the carapace of Emerita analoga; $\mathbf{b}$ floss-like mat of green macrolage epibiont in the sediment surface, indicating the presence of a buried Emerita analoga (dashed line)

non-fouled animals, and (3) estimated mortality rates due to predation of $E$. analoga with and without epibiosis.

\section{Methods}

\section{Study site}

The study was conducted during austral summer months in a beach (Playa Huaquillo, $200 \mathrm{~m}$ long) located south of the Ancón Bay (central Peru: $11^{\circ} 46^{\prime} \mathrm{S}, 77^{\circ} 11^{\prime} \mathrm{W}$ ). The beach is delimited by rocky cliffs and rock outcrops and is exposed to a moderate wave action. Its morphodynamic state corresponds to an Intermediate Type I beach (sensu Short and Wright 1983), with a mean grain size of $0.25 \mathrm{~mm}$ and a mean slope of $2.75 \%$ (Firstater et al. 2009). Tides have a mixed semidiurnal regime and average amplitude of $0.54 \mathrm{~m}$ (Dirección de Hidrografía y Navegación 2006). The area is characterized by high nutrient input due to upwelling and probably due to organic loads of anthropogenic origin, and with low oxygen concentration 
due to stagnation (Tarazona et al. 2003; Firstater et al. 2009).

\section{Emerita analoga density and epibiosis prevalence}

We conducted three samplings of E. analoga density: one in December 2005, the other in February 2006, and the last in April 2007. Samplings were performed at three different intertidal levels: the uppermost was performed on moist but unsaturated sand $\sim 2 \mathrm{~m}$ above the effluent line (thereafter "retention zone", sensu Salvat 1964), the other $\sim 2 \mathrm{~m}$ below the effluent line (thereafter "upper swash zone"), and the lowermost in the lower limit of the swash zone (thereafter "lower swash zone"). No samplings were conducted in the dry sand zone, as previous surveys indicated that no animals were present there. Our observations suggested that fouled and non-fouled animals are more abundant in the shallow subtidal zone; thus, in April 2007, we also sampled that zone (between 0.5 and $1 \mathrm{~m}$ depth). All samplings were done along ten equally spaced transects perpendicular to the shoreline. One sampling unit was collected along each transect and at each shore level with a core of $0.025 \mathrm{~m}^{2}$ and $0.15 \mathrm{~m}$ depth. The collected material was sieved through a 1-mm mesh, and E. analoga individuals were placed in numbered plastic bags. In the laboratory, all individuals were sexed (under a dissecting microscope); separated into juveniles, males, females without eggs, and ovigerous females, discriminating in each case the fouled animals; and measuring them to the nearest $0.01 \mathrm{~mm}$ (carapace length [CL]; from the tip of the rostrum to the distal scoop). Megalopae were not included in this analysis. Densities of fouled and non-fouled E. analoga were compared among levels of the shore and sampling dates with factorial ANOVAs (Zar 1999). Size distributions were compared among shore levels at each sampling date with Kolmogorov-Smirnov two-sample test (Zar 1999). Mean sizes of fouled and non-fouled E. analoga were compared among sexes, levels of the shore, and sampling dates with factorial ANOVAs (Zar 1999). For ANOVA's, data were log transformed to meet parametric assumptions (Zar 1999). When interactions between factors were significant, multiple comparisons Tukey test was used (Zar 1999).

\section{Birds abundance and predation on Emerita analoga}

Quantification of predation rates by birds was performed weekly from November 2005 to March 2006 by periods of two consecutive days. Most observations started at mid-morning $(\sim 9: 00)$ and ended at the early afternoon $(\sim 16: 00)$, and complementary observations were conducted at daybreak $(\sim 6: 00)$ and before sunset $(\sim 18: 00)$ to account for possible variations in foraging behavior. Bird species present were identified using Clements and Shany's (2001) field guide. To quantify predation rates, focal observations were conducted at a distance of no more than $50 \mathrm{~m}$ from the birds with binoculars $(16 \times 50)$, and data was saved into a portable tape recorder. Each bird was observed during periods of 5-10 min, completing a total of $29 \mathrm{~h}$ of focal observations. The following categories of behavior were recorded: (1) peck: striking at the substrate with the bill, (2) prey capture: prey captured from the substrate, and (3) swallow: swallowing action after the capture of a prey. Handling time is the time elapsing from the capture of a prey until it is swallowed. The following categories of prey items were identified: (1) E. analoga without epibiosis, (2) E. analoga with macroalgae epibiont, and (3) other items. Because assumptions for parametric tests were not meet, predation rates and handling times on E. analoga with and without epibiosis were compared for each bird species with the non-parametric KolmogorovSmirnov two-sample test (Zar 1999). To evaluate preference for fouled or non-fouled E. analoga, the Chesson's alpha index (Chesson 1978) was used. The index measures an invariant degree of preference on the part of the predator (Pearre 1982). The index is:

Chesson's alpha $=\left(r_{i} / p_{i}\right) / \sum_{i}\left(r_{i} / p_{i}\right)$

where $r_{i}$ and $p_{i}$ are the proportion of prey item $i$ in the diet and the environment, respectively. Therefore, this index indicates the preference of a consumer for a food type relative to the other food types present. In our case with two food types (i.e., fouled and non-fouled E. analoga), values $>0.5$ indicate preference for that prey.

To calculate the daily mean number of birds foraging in the beach along a day, we recorded the total number of individuals feeding or resting twice at each sampling day. The daily mean number of birds was the average of both censuses. In all possible cases, we identified the beach zone (i.e., lower and upper swash, retention and dry zones) where birds fed or rested.

\section{Mortality of Emerita analoga caused by birds}

Only mortality caused by Larus modestus was calculated, given that the other bird species occurred at too low numbers to include them into the analysis. In this study, mortality was defined as the fraction of fouled and nonfouled E. analoga consumed that were present in the intertidal area and thus accessible to predation by birds; thus, this value does not represent the mortality rates for the entire population of E. analoga, since subtidal animals were not included. Mortality was calculated as follows: 
$M_{f, n f}=\left(N p \times B \times F_{f, n f}\right) /\left(N e_{f, n f}\right)$

where $M$ is the mortality rate; $N p$ is the daily mean number of predators present in the beach and $B$ is the fraction of predators that were actively foraging, both $N p$ and $B$ were obtained from the bird censuses; $F$ is the predation rate, estimated from the focal observations; $\mathrm{Ne}$ is the number of intertidal $E$. analoga, and $f$ and $n f$ indicate the fouled and non-fouled $E$. analoga, respectively. $\mathrm{Ne}$ was estimated from the core samplings of December 2005 and February 2006 (i.e., within the period in which we made bird observations). Total abundance of $E$. ana$\log a$ was estimated separately for each sampling date and only for the swash zone (no animals were found in the retention zone, see Results). For this, the average density obtained with the core samplings $(N=20 ; 10$ sampling units at each the upper and lower swash zones) was multiplied by the total area of the swash zone. The area of the swash zones was estimated by multiplying the width of the zone by the length of the beach. The width of the swash zone was measured with three parallel transects established between the effluent line and the lowest tide mark, indicated by bore collapse. We chose to use the two values of total abundance estimations (i.e., one for each sampling date), instead of each value obtained in each sampling unit, as these yielded zero animals in some instances, disabling the calculation of mortality. Because we wanted to estimate daily mortalities, we calculated daily predation rates by considering that birds forage during sunlight hours (i.e., on average $12 \mathrm{~h}$ during the study season; Dirección de Hidrografía y Navegación 2006). Our observations indicated that the larger animals were fouled (see Results). Thus, given that prey size may influence the preference by birds (e.g., Goss-Custard 1977), but we were unable to account for this during focal observations, to avoid size as a confounding factor, we also evaluated mortality by considering that all animals consumed were within the size range of fouled animals or larger (i.e., by only including these animals in the calculation of $N e_{f}$ ).

To compare proportions of fouled and non-fouled E. analoga consumed, the distribution of all of the possible mortality values of fouled E. analoga was generated by multiplying each value of $N p \times B$ (i.e., the number of birds actively foraging) by each value of $F_{f}$ and dividing it by each of both December 2005 and February 2006 values of $N e_{f}$; in an analogous way, the distribution of all of the possible mortality values of non-fouled $E$. analoga was generated by multiplying each value of $N p \times B$ by each value of $F_{n f}$ and dividing it by each of both December 2005 and February 2006 values of $N e_{n f}$. This yielded distributions of 13152 values of mortality. For both distributions, standard normal confidence limits (Manly 1998) were constructed to evaluate significant differences in the percentage of fouled and non-fouled E. analoga consumed.

\section{Results}

Emerita analoga density and epibiosis prevalence

Density of E. analoga was higher in the lower than in the upper swash zone in all sampling dates (two-way ANOVA, $F_{1,54}=22.53, P<0.001$; Fig. 2 ), and mole crabs were never found in the retention zone. The sampling of April 07 revealed that the density of E. analoga in the subtidal zone was not different from that of the lower swash zone, and at both levels, the densities were higher than in the upper swash zone (one-way ANOVA, $F_{2,27}=13.26, P<0.001$; Tukey HSD test, $P<0.005$ for the significant differences; Fig. 2). Size distributions of E. analoga differed between the upper and lower swash levels at all sampling dates and between the lower swash and subtidal zone in the sampling of April 07 (K-S two-sample test, $P<0.05$ in all of the cases; Fig. 3); although there were no differences between the subtidal and upper swash zone (K-S two-sample test, $P>0.05$; sampling of April 07; Fig. 3). These differences, however, were not consistent along sampling dates: in Dec 05 , the differences may be attributed to a larger proportion of mid-sized animals in the lower swash zone; in Feb 06, these differences can be explained by the presence of more animals of the larger size classes in the lower swash zone and smaller animals in the upper swash zone; in April 07, large-size animals were present in the lower zones (i.e.,

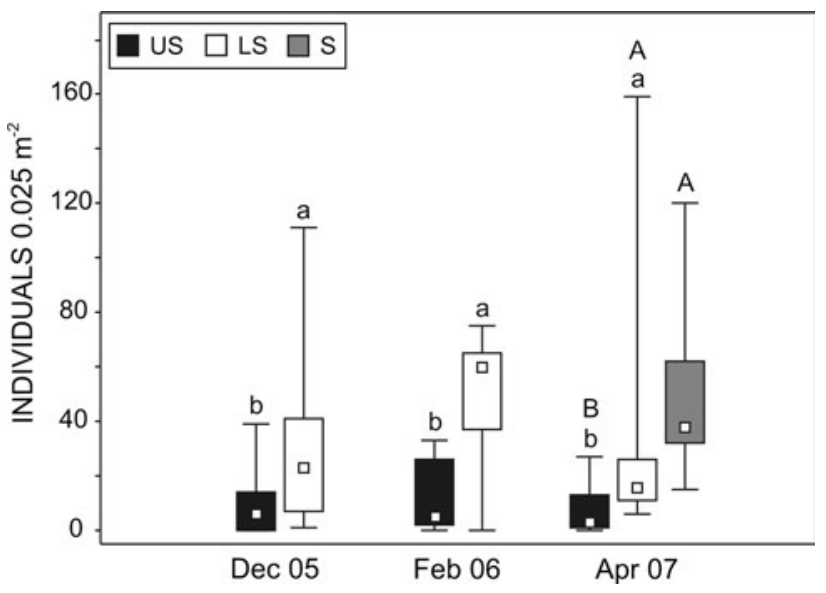

Fig. 2 Densities of Emerita analoga (individuals $0.025 \mathrm{~m}^{-2}$ ) in the upper swash (US), lower swash (LS), and subtidal (S) zones in the three sampling dates. Different lowercase letters indicate differences between the upper and lower swash zone after two-way ANOVA; different uppercase letters indicate differences among the three shore levels in April 07 after one-way ANOVA. Here and thereafter, vertical lines represent 0.01 and 0.99 percentiles, box limits are the 0.25 and 0.75 percentiles, and symbols within boxes are the median 


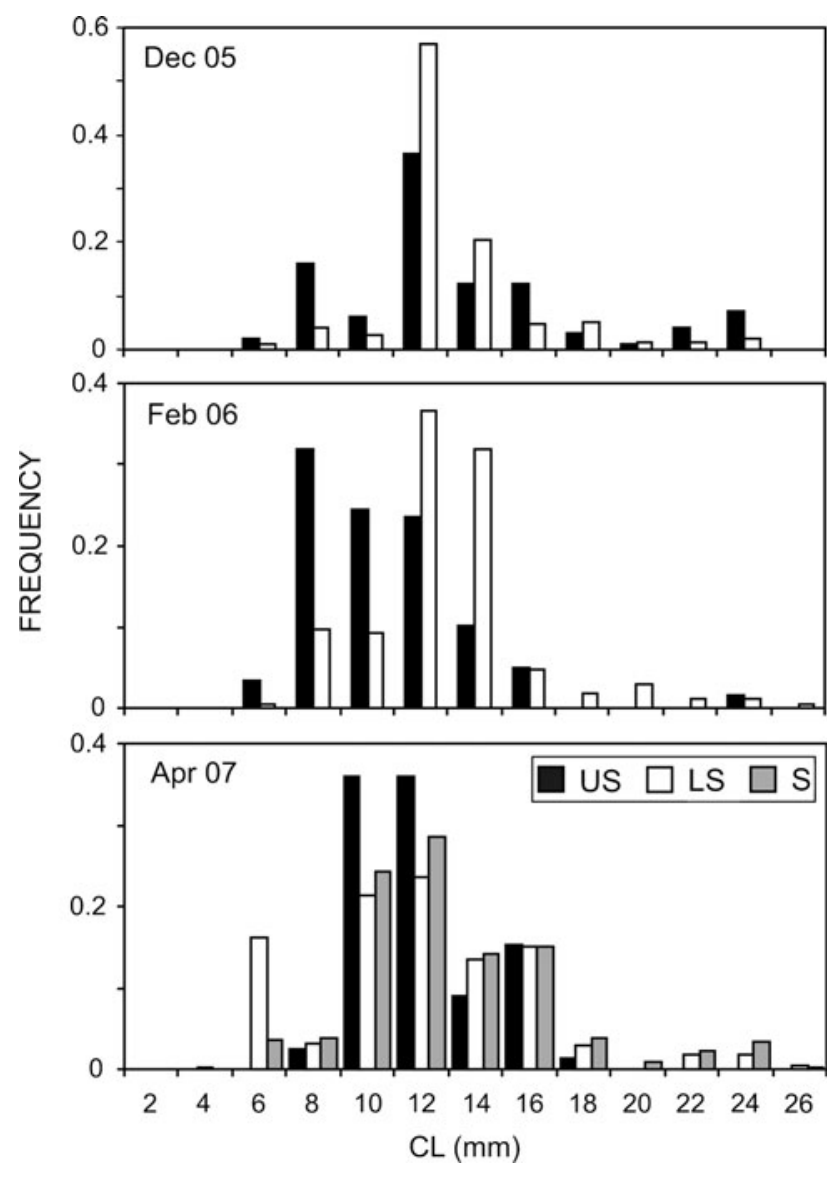

Fig. 3 Size frequency distributions of Emerita analoga in the intertidal levels sampled in (a) December 05, (b) February 06, and (c) April 07

subtidal and lower swash zones), but also a high number of recruits were found in the lower swash zone (Fig. 3).

Fouled animals were only found in the subtidal and the lower swash zone (Fig. 4). Epibiosis prevalence in the lower swash zone was 1.12, 2.57, and 1.33\% in Dec 05, Feb 06, and April 07, respectively; for the whole intertidal zone (i.e., lower and upper swash zones pooled), epibiosis prevalence was $0.88,2.12$, and $1.11 \%$ in Dec 05, Feb 06, and April 07, respectively. In the subtidal zone (April 07), epibiosis prevalence was $8.07 \%$. Despite the low overall prevalence in the intertidal and subtidal zone, epibiosis affected mainly the larger animals. Only females were found fouled in the lower swash zone (Fig. 4). Within the size range affected at this level of the shore $(18-23 \mathrm{~mm}$ CL; see Fig. 4), between 20 and $38 \%$ of the animals were fouled. In non-ovigerous and ovigerous females, epibiosis prevalence was $2.8-5.8$ and $17.6-66.7 \%$, respectively. Fouled females of the lower swash zone were larger than those non-fouled (both ovigerous and non-ovigerous grouped given the low number of fouled females found; two-way ANOVA, $F_{1,222}=31.0, P<0.0001$; Fig. 4), and those sampled in December 2005 were larger than those

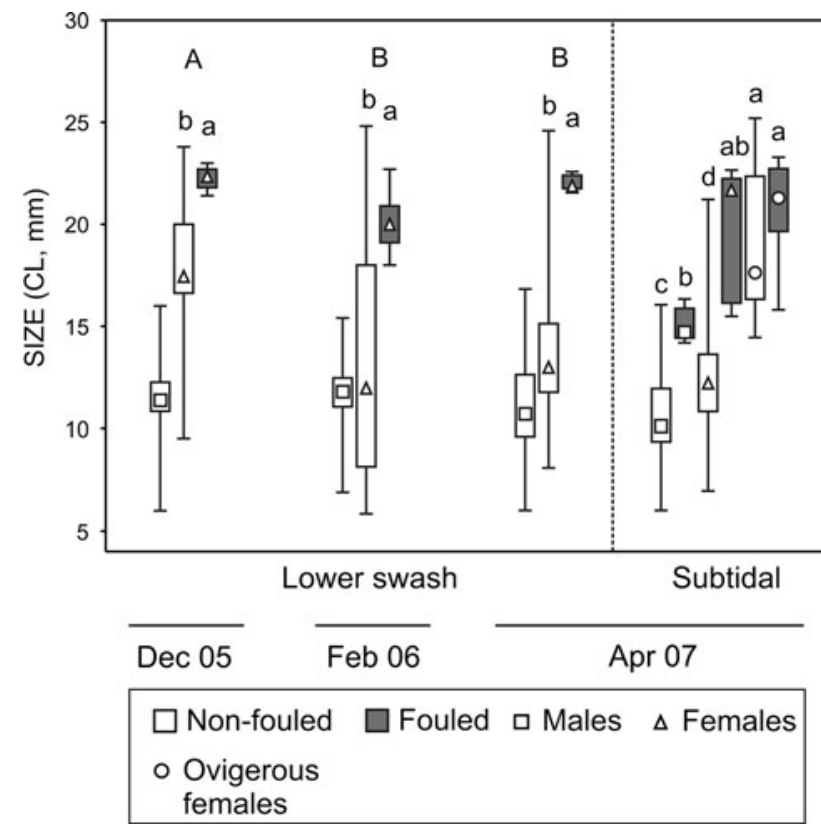

Fig. 4 Size (CL, mm) of fouled and non-fouled Emerita analoga in the lower swash (only females) and subtidal zones (both males and females). Ovigerous and non-ovigerous females were pooled for the analysis in the lower swash zone, given the low numbers of fouled non-ovigerous females found. Males from the lower swash zone were included in the figure but were not compared. Different lowercase letters indicate size differences between fouled and non-fouled females. Different uppercase letters indicate size differences among sampling dates. Different analyses were conducted for the lower swash and subtidal zones

from February 2006 and April 2007 (two-way ANOVA, $F_{2,222}=3.96, P<0.05$; Tukey HSD test, $P<0.001$ for the significant contrasts; Fig. 4). In the subtidal zone (sampling from April 07), both males and females were found fouled (Fig. 4), and 33\% of the animals within the size range affected were fouled. In males, non-ovigerous, and ovigerous females of the subtidal, epibiosis prevalence was $4.9,5.3$, and $85.7 \%$, respectively. There, a significant sex $\times$ epibiosis interaction was found (Table 1), since fouled males and fouled females were larger than nonfouled males and females, respectively; but fouled and nonfouled ovigerous females were not different. Furthermore, there were no size differences among fouled non-ovigerous females and both fouled and non-fouled ovigerous females (Fig. 4; Table 1).

Birds abundances and predation on Emerita analoga

Bird species present in the beach were the gray gull Larus modestus, the Franklin's gull Larus pipixcan, the bandtailed gull Larus belcheri, the black oystercatcher Haematopus ater, the common oystercatcher Haematopus palliatus, and the whimbrel Numenius phaeopus (Table 2). All of these species were observed capturing and eating 
Table 1 Results of the two-way ANOVA for the differences in size between fouled and non-fouled animals for the subtidal zone

\begin{tabular}{llrlll}
\hline Effect & SS & \multicolumn{1}{c}{ d.f. } & MS & \multicolumn{1}{l}{$F$} & $P$ \\
\hline Sex & 0.85 & 2 & 0.43 & 56.32 & 0.0000 \\
Epibiosis & 0.45 & 1 & 0.45 & 59.49 & 0.0000 \\
Sex $\times$ Epibiosis & 0.12 & 2 & 0.06 & 7.78 & 0.0005 \\
Error & 3.40 & 450 & 0.01 & & \\
\hline
\end{tabular}

E. analoga with variable intensity, but they also fed on stranded remains and little unidentified items.

Larus modestus was the most abundant bird species along the sampling dates and was the only bird species present in the beach in all of the days of observation (Table 2). Focal observations of 274 L. modestus were performed for a total of $1354 \mathrm{~min}$ (Table 2). On average, $39 \%$ of L. modestus individuals observed in a day were feeding, while the other $61 \%$ were resting. L. modestus fed mainly along the swash zone (98\% of the observations), employing different foraging tactics. Sometimes, they made short runs or flights to the lower swash zone when the waves recede, pecking and probing actively in the sand, and returning up fast when waves come again; other times, they ran or flew directly to a prey in the same zone. Occasionally, they were also observed pecking actively in the sand while walking along the swash zone. Predation rates of $L$. modestus on fouled E. analoga were higher than on non-fouled animals (Kolmogorov-Smirnov 2-sample test, $P<0.001$; Fig. 5).

Haematopus ater was not particularly abundant throughout the observation days (mean $=0.36$ individuals day $^{-1}$, Table 2), but it was observed actively searching and preying on E. analoga when was present in the beach. Focal observations of $38 \mathrm{H}$. ater were performed for a total of 190 min. Like L. modestus, H. ater fed mainly along the swash zone (98\% of the observations). Predation rates on fouled and non-fouled individuals were not different (Kolmogorov-Smirnov 2-sample test, $P>0.1$; Fig. 5). A high proportion of small unidentified items $(23 \%$ of the total prey consumed) were also consumed.

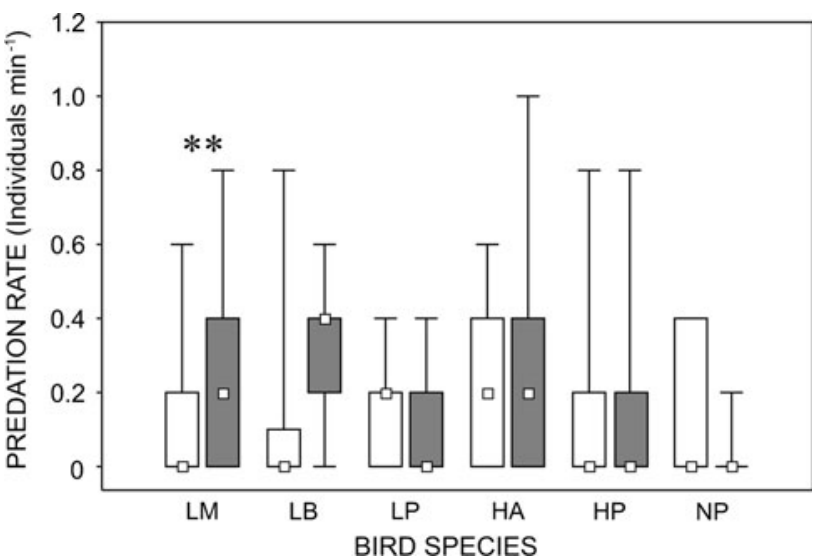

Fig. 5 Predation rates (individuals $\min ^{-1}$ ) on non-fouled (squares, gray boxes) and fouled (triangles, white boxes) Emerita analoga for each bird species. Asterisks indicate significant differences $(P<0.05)$ between fouled and non-fouled individuals. LM, Larus modestus; LB, Larus belcheri; LP, Larus pipixcan; HA, Haematopus ater; HP, Haematopus palliatis; NP, Numenius phaeopus

The other bird species (L. belcheri, L. pipixcan, H. palliatus, and $N$. phaeopus) occurred sporadically in the beach or preyed on E. analoga only occasionally (Table 2). Their predation rates on fouled and non-fouled E. analoga were variable and no differences were found (KolmogorovSmirnov 2-sample test, $P>0.05$ for all of the cases; Fig. 5).

Despite this variability in the predation rates, all of the bird species preferred fouled over non-fouled E. analoga (Chesson's alpha $>0.96$ in all of the cases), being eaten at a much higher proportion than their availability in the intertidal.

\section{Mortality of Emerita analoga caused by birds}

Only L. modestus was able to consume, on average, $35.4 \%$ of the intertidal fouled $E$. analoga day $^{-1}$, and $0.1 \%$ of nonfouled intertidal E. analoga day $^{-1}$. Estimated confidence limits indicated that this difference was significant (proportion of fouled individuals consumed: $X_{\text {fouled }}=0.354$, $\mathrm{SD}=0.519 ;$ median $=0.171 ; 95 \%$ confidence limits:

Table 2 Summary of the results of the bird censuses and focal observations

\begin{tabular}{lllllll}
\hline & $\begin{array}{l}\text { Larus } \\
\text { modestus }\end{array}$ & $\begin{array}{l}\text { Larus } \\
\text { pipixcan }\end{array}$ & $\begin{array}{l}\text { Larus } \\
\text { belcheri }\end{array}$ & $\begin{array}{l}\text { Haematopus } \\
\text { ater }\end{array}$ & $\begin{array}{l}\text { Haematopus } \\
\text { palliatus }\end{array}$ & $\begin{array}{l}\text { Numenius } \\
\text { phaeopus }\end{array}$ \\
\hline No. of days observed & 33 & 12 & 8 & 13 & 3 \\
Individual day & -1 (mean, SD) & $34.79(23.72)$ & $1.91(4.23)$ & $1.82(8.42)$ & $0.36(0.56)$ & $0.14(0.55)$ \\
Time of observation (min) & 1,354 & 70 & 40 & 190 & 25 & 35 \\
\hline
\end{tabular}

$\mathrm{N}$ of days observed is the total number of days that each bird species was observed in the beach, individuals day ${ }^{-1}$ is the mean number of individuals present in the beach each day, and time of observation is the total time (in minutes) each bird species was observed during the focal observations 
0-1.524; proportion of non-fouled individuals consumed: $X_{\text {non-fouled }}=0.001, \mathrm{SD}=0.002 ;$ median $=0 ; 95 \%$ confidence limits: 0-0.006). When considering that only animals within or larger than the size range of fouled E. analoga (i.e., $\geq 18 \mathrm{~mm} \mathrm{CL}$ ) were consumed, mortality was still different (proportion of non-fouled individuals consumed: $X_{\text {non-fouled }}=0.035, \mathrm{SD}=0.058$; median $=0$; 95\% confidence limits: $0-0.140$ ).

\section{Discussion}

Our results showed that the epibiotic association between green macroalgae and E. analoga has important effects on fouled individuals. The association is more frequent in larger animals, being adult females particularly affected. Bird observations and calculation of mortality rates indicate that fouled animals are more heavily consumed than those non-fouled of the same size class and hence of the same sex. We discuss here the factors associated with fouling that could have enhanced the susceptibility to predation.

At our study site and during the study period, E. analoga density increased from the upper to the lower sampled zones, and fouled individuals were only found in the lowest zones (i.e., the lower swash and subtidal zones). The pattern of increased densities of E. analoga to the lower zones is also present throughout the year at our study site (Firstater et al. 2009) and matches well with its acrossshore zonation in beaches close to the end of the reflective state (e.g., Jaramillo et al. 2000; Lastra et al. 2004); although the abundance of E. analoga across the shore can also vary seasonally, across the tidal cycle and with the beach morphodynamics (e.g., Cubit 1969; Jaramillo et al. 2000; Dugan et al. 2004).

The epibiosis prevalence during the study period was relatively low for the entire population; however, larger animals, mainly adult females, were mostly susceptible to fouling. In decapod crustaceans, the epibiosis prevalence commonly increase with the size and age of individuals (e.g., Gili et al. 1993; Lovrich et al. 2003), since the intermolt duration increases with the age and size of the crabs (Siegel 1984; Gili et al. 1993; Lovrich et al. 2003) and epibionts are shed along with their exuvia during molting (e.g., Gili et al. 1993). Female E. analoga are larger and their longevity is twice than that of males (e.g., Contreras et al. 1999) and thus they offer more time for fouling species to settle and grow (Firstater et al. 2009). In addition, E. analoga is normally buried leaving the anterior part of the carapace and the first appendices out of the sand (e.g., Villegas et al. 2005), and hence larger individuals may also have a larger area for algae sporelings to settle and growth.
A differential size distribution across the beach has been commonly reported for $E$. analoga populations, being the larger animals relatively more abundant in the lower zones (e.g., Penchaszadeh 1971; Sánchez and Alamo 1974; Alvitres et al. 1998). This pattern was also found at our study site and may explain the higher prevalence of epibiosis at low shore levels. In addition, fouling by itself can affect the across-shore distribution of the animals via swash currents (see Dugan et al. 2000; Manning and Lindquist 2003). Fouling usually increases dragging and buoyancy of the animals (e.g., Wahl 1996) and thus fouled animals, less capable of dealing with swash conditions because of different burrowing abilities and swash behaviors (see Dugan et al. 2000; Manning and Lindquist 2003), can shift from the swash zone to the shallow subtidal, where physical conditions are more stable. In addition, it has been experimentally demonstrated that the reported epibiosis increases the burrowing time of $E$. analoga (Firstater et al. 2009). This negative effect of epibiosis on burrowing behavior may be particularly important during the tidal migrations of E. analoga. Tidal migrations may allow animals to maintain a position at a water depth not easily accessible to predatory fishes and birds (Jaramillo et al. 2000). When mole crabs moves up or down the shore along the tidal cycle with the wave wash or swash (e.g., Cubit 1969; Dugan et al. 2000; Jaramillo et al. 2000), the macroalgal epibionts would lead to a reduction or even impede the animals to burrow in the swash zone, exposing them for longer time and making them more vulnerable to detection and predation by birds. Our observations of birds that captured E. analoga by making short runs to the lower shore when waves recede and exposed the area, using a similar visual feeding tactic previously reported for L. modestus preying on E. analoga (e.g., Ryan et al. 1987; Blokpoel et al. 1992), support this explanation. Furthermore, the feeding behavior and prey preference of birds could be related not only with a reduced burrowing ability of fouled individuals, but also with the attractive effect of the algae mat that could make them more conspicuous and readily detectable by visual predators. Although we were not able to differentiate whether birds preyed on fouled animals in the active swash because they burrowed slowly (or were unable to burrow) or because they were more conspicuous, the visual feeding tactic employed by the more abundant birds (i.e., L. modestus) indicate that they can promptly detected them, even if they are already buried, as the macroalgae frond remains above the sediment surface evidencing their presence. In addition, it has been shown that body condition is positively correlated with fouling in $E$. analoga, probably because fouling forces animals to spend more time feeding in the shallow subtidal rather than dealing with the harsh conditions of the swash zone (Firstater et al. 2009). Thus, increased profitability of 
the animals induced by fouling may also explain the bird preference.

It has been demonstrated that the prevalence and abundance of parasites in E. analoga relates with the abundance of birds preying on them (Smith 2007). In our case, because parasites may affect the burrowing behavior of their hosts (e.g., Swennen 1969; Curtis 1987; Poulin and Latham 2002), it would be reasonable to suppose that parasitized E. analoga are more susceptible to fouling and in turn to predation. However, since fouled animals burrow at similar rates than those non-fouled when the epibiotic algae is experimentally removed (Firstater et al. 2009), we suggest that parasites are not related to epibiosis and thus with increased predation on $E$. analoga, at least by affecting their burrowing ability. In addition, despite the size of the prey may also influence the food preference by birds (e.g., Goss-Custard 1977), L. modestus consumes a broad range of $E$. analoga sizes (range between 0.2 and $1 \times$ bill length, mean $=0.52 \times$ bill length; Ryan et al . 1987). Furthermore, mortality of fouled individuals was still higher than that of those non-fouled when considering that L. modestus consumed only large animals; thus, we suppose that their preference for fouled mole crabs relates epibiosis or with the associated factors above mentioned, but not with the larger size of the animals, at least within the size ranges affected.

Only L. modestus is able to remove $35 \%$ of the fouled animals from the intertidal zone everyday, indicating that predation may be an important factor regulating the abundance of fouled animals in the intertidal. Nevertheless, to keep removal rates in the calculated levels, fouled $E$. analoga must be replaced continuously from the subtidal; otherwise they would disappear from the intertidal within a few days. Despite epibiosis prevalence increases to the subtidal zone, the subtidal fraction of the fouled population should be huge to replace the fouled individuals eliminated by predation. Instead, rates of attachment and growth of macroalgae may be high enough to rapidly produce new fouled animals. Enteromorpha spp. can germinate within few hours once spores have attached on a suitable surface (Callow et al. 1997; Callow and Callow 2002), and adults can grow up to $21 \%$ per day when environmental conditions are optimal (Taylor et al. 2001). Water temperature, high nutrient input due to upwelling, and low oxygen concentration due to stagnation (Tarazona et al. 2003) might facilitate macroalgal growth at our study site during warmer months, when fouled animals are present in the beach (Firstater et al. 2009).

Beaches close to the end of the reflective state are characterized by high variability due to the increased magnitude of the erosion-accretion dynamics (Brown and McLachlan 1990; Brazeiro 2001) and hence beach macrofauna is generally considered to be mainly physically controlled (e.g., Defeo and McLachlan 2005). During periods of beach erosion, E. analoga may disappear from the intertidal zone and become subtidal (Jaramillo et al. 2000), but also to get locally extinct if climatic conditions get harsher (see Brazeiro 2001). Thus, it would be expected that the occurrence of large numbers of fouled $E$. analoga in the intertidal zone of our beach, and thus to be available for predatory birds, takes place when the swash zone is stable due to steady weather conditions and when environmental variables facilitates rapid algal growth.

Because predation pressure changed as a consequence of altered behavior and not an abundance increase of the predator, this interaction qualifies as an "interaction modification", as opposed to an "interaction chain", with serial direct effects (Wootton 1993). This is, by directly affecting the burrowing ability of mole crabs, by enhancing its visual attractiveness, or by increasing its profitability (i.e., increasing its body condition); the interaction represents a negative indirect effect on the host by increasing the predation pressure by birds. Besides those observed at our study site, other resident and migratory birds, including the Common Tern Sterna hirundo and the Rudy Turnstone Arenaria interpres, have been observed preying on $E$. analoga (Blokpoel et al. 1992). We have also seen large flocks of $N$. phaeopus (>90 individuals) feeding on E. analoga, including fouled individuals, in small beaches within the Ancón Bay, next to our study sites (F. Hidalgo, personal observation.). In addition to birds, other visual and tactile predators such as crabs (e.g., ghost crab Ocypode gaudischaudii: Koepcke and Koepcke 1953) and fishes (e.g., the sciaenids Menticirrhus ophicephalus, Sciaena deliciosa, Cilus gilberti: Alvitres et al. 1999; Vargas et al. 1999) usually prey on $E$. analoga in the region and might take advantage of fouled animals, both in the intertidal but also in the subtidal zone, where birds are less effective. Nevertheless, macroalgae may not be equally attractive for each predator species. For example, epibiosis by hydrozoans in the infaunal clam Donax variabilis facilitates predation by crabs through increasing their ability to detect them, but protects clams against a fish predator via chemical signaling (Manning and Lindquist 2003). Similarly, barnacle epibionts in Mytilus edulis enhance predation by shore crabs, while they decrease predation by a starfish (Wahl et al. 1997; Laudien and Wahl 1999). In our study, whether macroalgae facilitates or inhibits predation by crabs and fishes on E. analoga was not assessed; thus, it is unclear which are the combined effects of all predators on the entire E. analoga population. Nevertheless, whatever the net effect on the host, Enteromorpha spp. may benefit from the association by gaining a hard substrate for attachment in an environment where it could not otherwise occur (e.g., Wahl 1996; Creed 2000; Manning and Lindquist 2003), although it can also be consumed with the host. 
In summary, our results show that epibiosis, possibly by affecting the appearance, burrowing ability or profitability, has important consequences for larger $E$. analoga by increasing their mortality rate due to bird predation in the intertidal zone. This may be particularly important if it is taken into account that the larger adult females, as is this case, can represent the major reproductive output of the population (e.g., Dugan et al. 1991; Contreras et al. 1999). Nevertheless, the importance of birds in restricting the abundance of fouled E. analoga in the intertidal must be limited to periods when calm swash conditions prevails, allowing the persistence of E. analoga in the intertidal, and when environmental factors (e.g., water temperature, nutrient, and oxygen concentration) benefit rapid settlement and growth of Enteromorpha spp. on the animals.

Acknowledgments We thank Dr. J. Tarazona who facilitated his laboratory to our group and P. Ribeiro for statistical advice. We are grateful with Marina de Guerra del Perú and especially with M. Magnani and R. Whittembury to allow us the access to the study sites. We also thank O. Defeo and one anonymous reviewer for their comments which greatly improved the manuscript. This study was conducted and financed in the frame of the EU-project CENSOR (Climate variability and El Niño Southern Oscillation: Impacts for natural resources and management, contract 511071).

\section{References}

Alvitres V, Gutiérrez R, Veneros B, Chanamé J, Fupuy J (1998) Distribución de la población de Emerita analoga, durante abriloctubre 1995, playas de Trujillo, La Libertad-Perú. Rev Asoc Peru Ecol 1:65-71

Alvitres V, Chanamé J, Fupuy J, Chambergo A, Cortez M (1999) Cambios en la prevalencia de helmintos parásitos de Emerita analoga por efecto de "El Niño 1997-98". Rev Peru Biol Vol. Extraordinario $69-77$

Blokpoel H, Boersma DC, Hughes RA, Tessier GD (1992) Foraging by Larids on sand crabs Emerita analoga along the coast of Southern Peru. Ardea 80:99-104

Brazeiro A (2001) Relationship between species richness and morphodynamics in sandy beaches: what are the underlying factors? Mar Ecol Prog Ser 224:35-44

Brown AC, McLachlan AM (1990) Ecology of sandy shores. Elsevier, Amsterdam

Callow ME, Callow JA (2002) Marine biofouling: a sticky problem. Biologist 49:1-5

Callow ME, Callow JA, Pickett-Heaps JD, Wetherbee J (1997) Primary adhesion of Enteromorpha (Chlorophyta, Ulvales) propagules: quantitative settlement studios and video microscopy. J Phycol 33:938-947

Chesson J (1978) Measuring preference in selective predation. Ecology 59:211-215

Clements JF, Shany N (2001) A field guide to the birds of Peru. Ibis Publishing Company, Verona

Contreras H, Defeo O, Jaramillo E (1999) Life history of Emerita analoga (Stimpson) (Anomura, Hippidae) in a sandy beach of South Central Chile. Est Coast Shelf Sci 48:101-112

Creed JC (2000) Epibiois on cerith shells in a seagrass bed: correlation of shell occupant with epizoite distribution and abundance. Mar Biol 137:775-782
Cubit J (1969) Behavioral and physical factors causing migration and aggregation of the sand crab Emerita analoga (Stimpson). Ecology 50:118-123

Curtis LA (1987) Vertical distribution of an estuarine snail altered by a parasite. Science 235:1509-1511

Defeo O, McLachlan A (2005) Patterns, processes and regulatory mechanisms in sandy beach macrofauna: a multi-scale analysis. Mar Ecol Prog Ser 295:1-20

Defeo O, Brazeiro A, de Alava A, Riestra G (1997) Is sandy beach macrofauna only physically controlled? Role of substrate and competition in isopods. Est Coast Shelf Sci 45:453-462

Dirección de Hidrografía y Navegación (2006) Tabla de Mareas 2006. Puertos de la Costa del Perú, Océano Pacífico-América del Sur'. Ministerio de Defensa, Marina de Guerra del Perú, Perú

Dugan JE, Wenner AM, Hubbard DM (1991) Geographic variation in the reproductive biology of the sand crab Emerita analoga (Stimpson) on the California coast. J Exp Mar Biol Ecol 150:63-81

Dugan JE, Hubbard DM, Lastra M (2000) Burrowing abilities and swash behavior of three crabs, Emerita analoga Stimpson, Blepharipoda occidentalis Randall, and Lepidopa californica Efford (Anomura, Hippoidea), of exposed sandy beaches. J Exp Mar Biol Ecol 255:229-245

Dugan JE, Jaramillo E, Hubbard DM, Contreras H, Duarte C (2004) Competitive interactions in macroinfaunal animals of exposed sandy beaches. Oecologia 139:630-640

Efford IE (1969) Egg size in the sand crab Emerita analoga (Decapoda, Hippidae). Crustaceana 16:15-26

Firstater FN, Hidalgo FJ, Lomovasky BJ, Gallegos P, Gamero P, Iribarne OO (2009) Effects of epibiotic macrophyte on the mole crab Emerita analoga in the central coast of Peru. J Mar Biol Assoc U K 89:363-370

Gili JM, Abello P, Villanueva R (1993) Epibionts and intermoult duration in the crab Bathynectes piperitus. Mar Ecol Prog Ser 98:107-113

Goss-Custard JD (1977) Optimal foraging and the size selection of worms by redshank, Tringa totanus, in the field. Anim Behav 25:10-29

Hubbard DM, Dugan JE (2003) Shorebird use of an exposed sandy beach in southern California. Est Coast Shelf Sci 58:41-54

Jaramillo E, Dugan JE, Contreras H (2000) Abundance, tidal movement, population structure, and burrowing rate of Emerita analoga (Anomura, Hippidae) at a dissipative and a reflective sandy beach in South Central Chile. PSZN I Mar Ecol 21:113127

Koepcke HW, Koepcke M (1953) Contribución al conocimiento de la forma de vida de Ocypode gaudichaudii Milne Edwards et Lucas (Decapoda, Crustacea). Pub Mus His Nat J P 13:1-46

Lastra M, Jaramillo E, López J, Contreras H, Duarte C, Rodriguez JG (2004) Population abundances, tidal movement, burrowing ability and oxygen uptake of Emerita analoga (Stimpson) (Crustacea, Anomura) on a sandy beach of South-Central Chile. PSZN I Mar Ecol 25:71-89

Laudien J, Wahl M (1999) Indirect effects of epibiosis on host mortality: seastar predation on differently fouled mussels. PSZN I Mar Ecol 20:35-47

Laudien J, Wahl M (2004) Associational resistance of fouled blue mussels (Mytilus edulis) against starfish (Asterias rubens) predation: relative importance of structural and chemical properties of the epibionts. Helgol Mar Res 58:162-167

Lépez I, Furet L, Aracena O (2001) Población de Emerita analoga (Stimpson 1857) en Playas Amarilla y Rinconada, Antofagasta: aspectos abióticos, bióticos y concentración de cobre. Gayana 65:55-76

Lovrich GA, Calcagno JA, Smith BD (2003) The barnacle Notobalanus flosculusas an indicator of the intermolt period of the male lithodid crab Paralomis granulosa. Mar Biol 143:143-156 
Manly BFJ (1998) Randomization, bootstrap and Monte Carlo methods in biology, 2nd edn. Chapman and Hall, London

Manning LM, Lindquist N (2003) Helpful habitant or pernicious passenger: interactions between an infaunal bivalve, an epifaunal hydroid and three potential predators. Oecologia 134:415-422

McLachlan A, Dorvlo A (2005) Global patterns in sandy beach macrobenthic communities. J Coast Res 21:674-687

Menge BA (1995) Indirect effects in marine rocky intertidal interaction webs: patterns and importance. Ecol Monogr 65:21-74

Pearre S Jr (1982) Estimating prey preference by predators: uses of various indices, and a proposal on another based on $X^{2}$. Can $\mathrm{J}$ Fish Aquat Sci 39:914-923

Penchaszadeh P (1971) Observaciones cuantitativas preliminares en playas arenosas de la costa central del Perú con especial referencia a las poblaciones de "muy muy" (Emerita analoga Crustacea: Anomura, Hippidae). Inst Biol Mar Mar del Plata 177:1-16

Poulin R, Latham DM (2002) Parasitism and the burrowing depth of the beach hopper Talorchestia quoyana (Amphipoda: Talitridae). Anim Behav 63:269-275

Ryan PG, Hockey PAR, Bosman AL (1987) The foraging behavior of Gray Gulls at a sandy beach. Wilson Bull 99:271-273

Salvat B (1964) Les conditions hydrodynamiques interstitielles des sédiments meubles intertidaux et la répartition verticale de la fauna endogée. C R Acad Sci Paris 259:1576-1579

Sánchez G, Alamo V (1974) Algunos aspectos de la biología del muy muy (Emerita analoga). Ser Inf Esp Inst Mar Peru 167:1-26

Short AD, Wright LD (1983) Physical variability of sandy beaches. In: McLachlan A, Erasmus T (eds) Sandy beaches as ecosystems. Dr W Junk Publishers, The Hague, pp 133-144

Siegel PR (1984) Food-induced size-specific molt synchrony of the sand crab, Emerita analoga (Stimpson). Biol Bull 167:579-589

Smith NF (2007) Associations between shorebird abundance and parasites in the sand crab, Emerita analoga, along the California coast. J Parasitol 93:265-273

Swennen C (1969) Crawling-tracks of the trematode infected Macoma balthica (L.). Neth J Sea Res 4:376-379
Takahashi K, Hirose T, Kawaguchi K (1999) The importance of intertidal sand-burrowing peracarid crustaceans as prey for fish in the surf-zone of a sandy beach in Otsuchi Bay, northeastern Japan. Fish Sci 65:856-864

Tarazona J, Gutiérrez D, Paredes C, Indacochea A (2003) Overview and challenges of marine biodiversity research in Peru. Gayana 67:206-231

Taylor R, Fletcher RL, Raven JA (2001) Preliminary studies on the growth of selected 'green tide' algae in laboratory culture: effects of irradiance, temperature, salinity and nutrients on growth rate. Bot Mar 44:327-336

Valiela I, McClelland J, Hauxwell J, Behr PJ, Hersh D, Foreman K (1997) Macroalgal blooms in shallow estuaries: controls and ecophysiological and ecosystem consequences. Limnol Oceanogr 42:1105-1118

Vargas M, Cifuentes S, Emparanza E (1999) Espectro trófico de peces concurrentes al área de crianza de Playa Chipana $\left(21^{\circ} 19^{\prime} \mathrm{S}-\right.$ $70^{\circ} 04^{\prime} \mathrm{W}$ ) del norte de Chile. Rev Biol Trop 47:597-600

Villegas MJ, Stotz W, Laudien J (2005) First record of an epibiosis between the sand crab Emerita analoga (Stimpson, 1857) (Decapoda: Hippidae) and the mussel Semimytilus algosus (Gould, 1850) (Bivalvia, Mytilidae) in southern Peru. Helgol Mar Res 60:25-31

Wahl M (1996) Fouled snails in flow: potential of epibionts on Littorina littorea to increase drag and reduce snail growth rates. Mar Ecol Prog Ser 138:157-168

Wahl M, Hay ME (1995) Associational resistance and shared doom. Oecologia 102:329-340

Wahl M, Hay ME, Enderlein P (1997) Effects of epibiosis on consumer-prey interactions. Hydrobiologia 355:49-59

Wootton JT (1993) Indirect effects and habitat use in an intertidal community: interaction chains and interaction modifications. Am Nat 141:71-89

Zar JH (1999) Biostatistical analysis. Prentice Hall, Englewood Cliffs, New Jersey 